ORIGINAL RESEARCH PAPER

\title{
BIOACTIVE COMPONENTS, ENZYMES INHIBITORY AND ANTIOXIDANT ACTIVITIES OF BIOFORTIFIED YELLOW MAIZE (ZEA MAYS L.) AND COWPEA (VIGNA UNGUICULATA L. WALP) COMPOSITE BISCUITS
}

EMMANUEL ANYACHUKWU IRONDI ${ }^{1 *}$, EMMANUEL OLADIPO AJANI ${ }^{1}$, OLAWALE MASHOOD ALIYU ${ }^{2}$, KAZEEM KOLEDOYE OLATOYE ${ }^{3}$, HASSAN TAIYE ABDULAMEED ${ }^{1}$, OSAYAME FUNMILAYO OGBEBOR ${ }^{1}$

\author{
${ }^{1}$ Department of Medical Biochemistry and Pharmacology, Kwara State University, Malete, \\ P.M.B. 1530, Ilorin, Nigeria \\ ${ }^{2}$ Department of Crop Production, Kwara State University, Malete, P.M.B. 1530, Ilorin, Nigeria \\ ${ }^{3}$ Department of Food Science and Technology, Kwara State University Malete, P.M.B. 1530, \\ Ilorin, Nigeria \\ *corresponding author: emmanuel.irondi@kwasu.edu.ng
}

Received on 24 February 2021

Revised on 22 April 2021

\begin{abstract}
This study evaluated the bioactive components, enzymes inhibitory and antioxidant activities of biofortified yellow maize (YM) and cowpea (CP) composite biscuits. Composites of YM and CP, mixed at the ratios of 100:0 (YM); 75:25 (YMCP-1); 50:50 (YMCP-2); 25:75 (YMCP-3) and 0:100 (CP), were used to bake composite biscuits designated YM-B, YMCP-1B, YMCP-2B, YMCP-3B and $\mathrm{CP}-\mathrm{B}$, respectively. Refined wheat flour (WT) served as the control biscuit (WT-B). The bioactive components (total carotenoids, total phenolics, tannins, total flavonoids and total saponins), enzymes (pancreatic lipase, $\alpha$-amylase, $\alpha$ glucosidase) inhibitory and antioxidant $\left(\mathrm{ABTS}^{*+}, \mathrm{DPPH}^{*}\right.$ scavenging and reducing power) activities of the flours and biscuits were determined. Total carotenoids content increased significantly $(p<0.05)$ with increasing proportion of YM, while total phenolics, tannins, total flavonoids and saponins contents, enzymes inhibitory and antioxidant activities increased with increasing proportion of $\mathrm{CP}$ in the composite flours and biscuits. Among the composite biscuits, YMCP-3B had the strongest $(p<0.05)$ enzymes inhibitory and antioxidant activities. The composite biscuits, especially YMCP-3B, may serve as functional biscuits for retarding the rate of fatty acids and glucose formation, and mitigating oxidative stress, which represent a clinical strategy for managing obesity and type 2 diabetes.
\end{abstract}

Keywords: bioactive components, composite biscuits, cowpea, digestive enzymes, yellow maize

https://doi.org/10.35219/foodtechnology.2021.1.06 


\section{Introduction}

Obesity, indicated by a body mass index (BMI) of $30 \mathrm{~kg} / \mathrm{m}^{2}$ or above, affects both adults and children (Alzaman and Ali, 2016; Bae et al., 2016). In the year 2015, 107.7 million children and 603.7 million adults had obesity globally (GBD, 2017); making it one of the greatest global health challenges in this century. It is characterized by the accumulation of excess fat in the adipose tissue, due to higher energy intake relative to energy expenditure (Hossain et al., 2007). Obesity, especially visceral obesity, is a major risk factor for type 2 diabetes (T2D), with about $80 \%$ of patients suffering from T2D being overweight or obese (GomezAmbrosi et al., 2011; Wander et al., 2012). Furthermore, it increases the odds of developing many common diabetic complications, such as cardiovascular diseases, retinopathy and dyslipidaemia in patients with T2D (American Diabetes Association, 2014). Obesity and T2D have oxidative stress as a denominator (Rani et al., 2016).

An important clinical approach for treating obesity and T2D is by inhibiting pancreatic lipase, $\alpha$-amylase and $\alpha$-glucosidase (Villiger et al., 2015; Irondi et al., 2018a). Pancreatic lipase, an enzyme component of the pancreatic juice, catalyzes the hydrolysis of dietary triacylglycerol to fatty acids and monoacylglycerols in the intestine (Li et al., 2011). Its inhibition slows down the production of fatty acids and their subsequent absorption, thereby serving as an index for testing the efficacy of a potential anti-obesity agent (Sugiyama et al., 2007). Similarly, $\alpha$-amylase and $\alpha$-glucosidase catalyze the digestion of dietary carbohydrates. First, $\alpha$-amylase present in the small intestine hydrolyzes the $\alpha-1,4$ bonds of starch, releasing oligosaccharides and disaccharides. The oligosaccharides and disaccharides are subsequently hydrolyzed by $\alpha$-glucosidase present in the brush border of the small intestine, producing absorbable monosaccharides, such as glucose and fructose (Tucci et al., 2010). Hence, $\alpha$-amylase and $\alpha$-glucosidase inhibition is a key clinical approach for managing postprandial hyperglycaemia in T2D, and a welldocumented mechanism by which several anti-diabetic agents express their effects (Irondi et al., 2018a; Kim et al., 2005).

The intake of energy-dense foods, characterized by high fat and sugar contents, promotes the development of obesity and T2D (Martinez-Saez et al., 2017). On the other hand, foods with a low sugar and a high fiber contents are beneficial in improving satiety, controlling blood glucose levels and body weight gain (Van et al., 2012). Consequently, the food industry has intensified efforts on producing high-fiber, low-fat/low-calorie foods, such as biscuits, in response to the public health concerns associated with the consumption of energy-dense foods in recent time. In doing so, biscuits made from whole grains were identified as good sources of bioactive components (Cukelj et al., 2017).

Biscuits are baked food products that are well-liked for their ready-to-eat nature, high nutritive value, and availability in various sizes and shapes at an affordable price. Usually, biscuits are formulated to be rich in fat and sugar, which makes consumers that are calorie-conscious to keep them off (Aggarwal et al., 2016). In addition to being an energy-dense snack, biscuits are deficient in the bioactive 
components of grain, including phytochemicals and dietary fiber that are beneficial to health due to the use of refined ingredients in baking them (Fardet, 2010). In an effort to produce functional biscuits for the calorie-conscious people and those suffering from obesity, T2D and other non-communicable diseases, the major ingredients of the biscuits are modified. Such modification includes use of artificial sweeteners, fat replacers and replacement of part or whole of the wheat flour with whole composite or multigrain flour (Aggarwal et al., 2016). Whole grains are rich sources of bioactive components, such as dietary fiber, polyphenolics and saponins that play important role in protecting against obesity and T2D (Irondi et al., 2019a).

Biofortified yellow maize (Zea mays L.) is an important dietary source of biologically active compounds, including polyphenolic compounds, carotenoids, anthocyanins and vitamin C (Alamu et al., 2018; Beta and Hwang, 2018). Health benefits such as antioxidant, antidiabetic and anti-obesity activities (Irondi et al., 2019a; Žilić et al., 2012) have been attributed to these bioactive components that are found in yellow maize. Similarly, cowpea (Vigna unguiculata L. Walp), a drought- and heat-tolerant grain legume, is a rich dietary source of protein, calories, vitamins and essential minerals for humans, especially in the semi-arid parts of the world (Sreerama et al., 2012; Awika and Duodu, 2017). It is also an important source of bioactive components such as peptides (Segura-Campos et al., 2011) and polyphenolic compounds (Irondi et al., 2019b) that have some health benefits.

The health benefits derivable from biofortified yellow maize, cowpea and their products can be optimized when they are consumed as composites rather than as individual food due to the synergy among their bioactive compounds. Hence, this study evaluated the bioactive components, enzymes inhibitory and antioxidant activities of biofortified yellow maize and cowpea composite biscuits.

\section{Materials and methods}

\section{Chemicals and reagents}

Alpha-amylase, Bacillus stearothermophillus $\alpha$-glucosidase, porcine pancreatic lipase, acarbose, orlistat, $p$-nitrophenyl butyrate, trolox, quercetin, L-ascorbic acid, 2,2'-azino-bis-3-ethylbenzthiazoline-6-sulphonic (ABTS), 2,2diphenylpicrylhydrazyl (DPPH), diosgenin, and gallic acid were Sigma (St. Louis, USA) products. All other chemicals used in the experiments were analytical grades.

\section{Samples collection and preparation}

Samples (1 kg each) of biofortified yellow maize (provitamin A yellow maize) and cowpea (IT10K-837-1) were procured from the Institute of Agricultural Research and Training, Ibadan, Nigeria, and the Department of Crop Production, Kwara State University, Malete, Nigeria, respectively. Subsequently, the samples were sorted and $200 \mathrm{~g}$ portion of each was ground into whole meal flour, which was 
packed hermetically in sample containers and stored at $-4^{\circ} \mathrm{C}$ during the experiments.

\section{Preparation of composite flours}

The whole meal flours of biofortified yellow maize (YM) and cowpea (CP) were mixed at the ratios of 100:0; 75:25; 50:50;25:75; 0:100 to obtain yellow maize and cowpea composite flours designated YM, YMCP-1, YMCP-2, YMCP-3 and CP, respectively. Refined wheat flour (WT) served as a control flour.

\section{Formulation and baking of biscuits}

The method described by Saha et al. (2011) was adopted to formulate the biscuits, with a slight modification. Sugar-free composite biscuits were formulated from the $\mathrm{YM}$ and $\mathrm{CP}$ composite flours (YM, YMCP-1, YMCP-2, YMCP-3 and CP) and were coded YM-B, YMCP-1B, YMCP-2B, YMCP-3B and CP-B, respectively. Refined wheat flour (WT) was used for the control biscuit (WT-B). Biscuit dough was prepared according to the following formula: flour $100 \mathrm{~g}$, shortening $30 \mathrm{~g}$, sodium chloride $0.6 \mathrm{~g}$, sodium bicarbonate $0.3 \mathrm{~g}$, ammonium bicarbonate $0.6 \mathrm{~g}$, water $20 \mathrm{~mL}$. The flour and shortening agent were thoroughly mixed for 5 minutes, using a kitchen mixing apparatus. Subsequently, dough water containing sodium bicarbonate, ammonium bicarbonate, sodium chloride and milk powder, as specified in the formula, was added to the mixture of the flour and shortening agent, and mixed thoroughly to obtain a uniform dough. Thereafter, the dough of each flour was kneaded with a rolling pin to obtain a uniform thickness. Thereafter, biscuits were cut into regular shapes with a cutter (diameter: $43 \mathrm{~mm}$ ) and baked on a tray covered with aluminium foil at $210^{\circ} \mathrm{C}$ for 10 minutes. After baking, the biscuits (Figure 1) were allowed to cool for 30 minutes, and stored in hermetic plastic containers for further analysis.

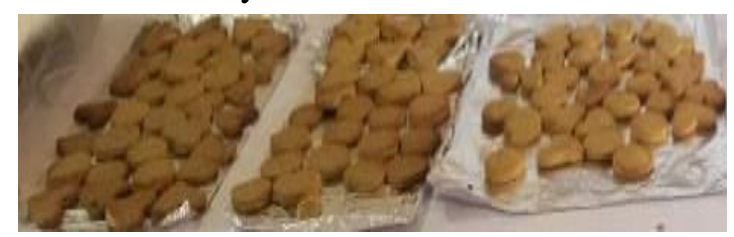

A

$\mathrm{B} \quad \mathrm{C}$

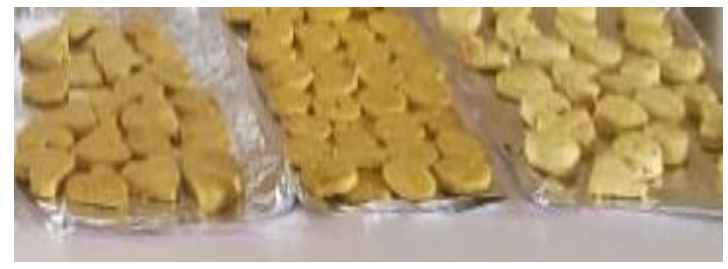

$\mathrm{D}$

$\mathrm{E}$

$\mathrm{F}$

Figure 1. Biscuits samples: A-cowpea biscuit (CP-B); B-25:75 (\% w/w) yellow maize and cowpea composite biscuit (YMCP-3B); C-50:50 (\% w/w) yellow maize and cowpea composite biscuit (YMCP-2B); D-75:25 (\% w/w) yellow maize and cowpea composite biscuit (YMCP-1B); E-yellow maize biscuit (YM-B); F-refined wheat flour biscuit (WTB) 
Preparation of flour and biscuit extracts

Extracts of flours and pulverized biscuit samples were prepared by soaking $2 \mathrm{~g}$ of each sample in $20 \mathrm{~mL}$ of absolute methanol overnight. Thereafter, the mixture was centrifuged at $4000 \mathrm{rpm}$ for 5 minutes, and the supernatant was collected by filtering through a filter paper (Whatman No. 2). The filtrate was concentrated at $45^{\circ} \mathrm{C}$ with the aid of a rotary evaporator, following which the extract was reconstituted with $6 \mathrm{~mL}$ of methanol (Engida et al., 2013).

Determination of bioactive constituents (total carotenoids, total phenolics, total flavonoids, tannins and total saponins)

Total carotenoid content of the samples was quantified as per the method described by Rodriguez-Amaya (1999). The method reported by Singleton et al. (1999) was followed to determine the total content of phenolics in the samples, and the results were presented in milligram gallic acid equivalent per gram of sample (that is, $\mathrm{mg}$ $\mathrm{GAE} / \mathrm{g}$ ). The level of total flavonoids in the samples was quantified based on the method reported by Meda et al. (2005), and the results were presented in milligram quercetin equivalent per gram of sample $(\mathrm{mg} \mathrm{QE} / \mathrm{g})$. The tannins level of the samples, presented in milligram tannic acid equivalent per gram of sample (that is, $\mathrm{mg}$ TAE/g) was analyzed by adopting the method reported by Amorim et al. (2008). For the quantification of total saponins level of the samples, the method described by Makkar et al. (2007) was adopted, and the results were presented in milligram diosgenin equivalent per gram of sample (that is, $\mathrm{mg} \mathrm{DE} / \mathrm{g}$ ).

\section{Enzymes inhibitory assays}

\section{Determination of pancreatic lipase inhibitory activity}

The pancreatic lipase inhibitory activity of samples was determined according to the protocol reported by Eom et al. (2013), in which orlistat was used as a reference inhibitor of pancreatic lipase. The enzyme solution was prepared by mixing $30 \mu \mathrm{L}$ of pancreatic lipase (10 units, in morpholinepropane sulphonic acid, $10 \mathrm{mM}$, and EDTA, $1 \mathrm{mM}$ of $\mathrm{pH} 6.8$ ) with $850 \mu \mathrm{L}$ of Tris buffer (containing Tris$\mathrm{HC} 1,100 \mathrm{mM}$, and $\mathrm{CaCl}_{2}, 5 \mathrm{mM}$; $\mathrm{pH} 7.0$ ). Thereafter, a mixture of $100 \mu \mathrm{L}$ of different dilutions of the sample extract (or orlistat) and $880 \mu \mathrm{L}$ of the enzyme solution was subjected to incubation for 10 minutes at $37^{\circ} \mathrm{C}$. Subsequently, $20 \mu \mathrm{L}$ of the substrate, comprising $p$-nitrophenyl butyrate $(10 \mathrm{mM})$ in dimethyl formamide, was dispensed into the mixture, and the hydrolytic reaction proceeded for 20 minutes at $37^{\circ} \mathrm{C}$. Finally, the absorbance of the $p$-nitrophenol formed by the hydrolytic reaction was read at $405 \mathrm{~nm}$, and the inhibition (\%) of pancreatic lipase by the extract was calculated.

\section{Determination of $\alpha$-amylase inhibitory activity}

The capacity of the samples to inhibit $\alpha$-amylase was determined following the protocol described by Kwon et al. (2008), using acarbose as a standard inhibitor. A mixture of equal volume $(500 \mu \mathrm{L})$ of varied concentrations of the extract of sample and sodium phosphate buffer solution (0.02 M; pH 6.9, containing $\mathrm{NaCl}, 0.006 \mathrm{M}$ ), containing $0.5 \mathrm{mg} / \mathrm{mL}$ of $\alpha$-amylase was subjected to incubation for 10 minutes at $37^{\circ} \mathrm{C}$. Afterwards, $500 \mu \mathrm{L}$ of the substrate solution $(1 \mathrm{~g}$ soluble starch dissolved in 
$0.02 \mathrm{M}$ sodium phosphate buffer) was dispensed into the reaction mixture, and it was subjected to incubation for 15 minutes at $37^{\circ} \mathrm{C}$. Starch hydrolysis was terminated by adding $1.0 \mathrm{~mL}$ of DNSA reagent (comprising 3,5-dinitrosalicylic acid, $1 \%$, and sodium potassium tartrate, $12 \%$, in $0.4 \mathrm{M} \mathrm{NaOH}$ ), followed by 5 minutes of incubation in a water bath at $100^{\circ} \mathrm{C}$. The reaction mixture was cooled to room temperature and diluted with $10 \mathrm{~mL}$ of water (distilled). Finally, the absorbance reading was measured at $540 \mathrm{~nm}$, and the inhibition (\%) of $\alpha$-amylase activity by the extract was calculated.

Analysis of $\alpha$-glucosidase inhibitory activity

The ability of the samples to inhibit the activity of $\alpha$-glucosidase was determined following the protocol reported by Kim et al. (2005), in which acarbose served as a standard inhibitor. A mixture, containing $\alpha$-glucosidase $(50 \mu \mathrm{L})$ and different concentrations of extract $(50 \mu \mathrm{L})$, was subjected to incubation for 10 minutes at $37^{\circ} \mathrm{C}$. Thereafter, $100 \mu \mathrm{L}$ of $3 \mathrm{mM}$ p-nitrophenylglucopyranoside (PNPG) dissolved in phosphate buffer $(20 \mathrm{mM}, \mathrm{pH}$ 6.9) was dispensed into the reaction mixture to initiate the hydrolytic reaction. The hydrolytic reaction proceeded for 20 minutes at $37^{\circ} \mathrm{C}$, after which a volume of $2 \mathrm{~mL}$ of $\mathrm{Na}_{2} \mathrm{CO}_{3}(0.1 \mathrm{M})$ was added to terminate it. Next, the absorbance of the $p$-nitrophenol formed by the hydrolysis of PNPG was read at $400 \mathrm{~nm}$, and the percentage inhibition of $\alpha$-glucosidase by the extract was calculated.

\section{Antioxidant activity assays}

Determination of 2,2-Azinobis (3-ethyl-benzothiazoline-6-sulfonic acid) radical cation $\left(\right.$ ABTS $\left.^{*+}\right)$ scavenging activity

The $\mathrm{ABTS}^{*+}$ scavenging activity of samples, expressed as trolox equivalent antioxidant capacity (TEAC), was analyzed as per the protocol reported by Re et al. (1999). To prepare the working reagent of $\mathrm{ABTS}^{*+}$, a mixture of equal amount (v:v) of aqueous solutions of $2.45 \mathrm{mM} \mathrm{K}_{2} \mathrm{~S}_{2} \mathrm{O}_{8}$ and $7 \mathrm{mM} \mathrm{ABTS}^{*+}$ was subjected to incubation at room temperature in a dark condition for 16 hours. The absorbance reading $(0.70 \pm 0.02)$ of the working $\mathrm{ABTS}^{*+}$ reagent at $734 \mathrm{~nm}$ was acheived by diluting it with ethanol, 95\%. Thereafter, $2.0 \mathrm{~mL}$ of the $\mathrm{ABTS}^{*+}$ reagent was mixed with $0.2 \mathrm{~mL}$ of the sample extract, and the mixture was incubated in a dark condition at room temperature for 15 minutes. The absorbance of the sample was read at $734 \mathrm{~nm}$, and the $\mathrm{ABTS}^{*+}$ scavenging activity was subsequently calculated from a calibration curve prepared using trolox.

Determination of 2,2-diphenyl-2-picrylhydrazyl radical (DPPH*) scavenging activity

The $\mathrm{DPPH}^{*}$ scavenging activity of samples was determined based on the procedure reported by Cervato et al. (2000). Ascorbic acid was used as a standard antioxidant. A total of $1.0 \mathrm{~mL}$ of varied extract concentrations (or ascorbic acid) was mixed with $3.0 \mathrm{~mL}$ of $\mathrm{DPPH}^{*}$ solution $(60 \mu \mathrm{M})$, and the mixture was incubated in the dark condition for 30 minutes at room temperature. Afterwards, the absorbance reading was taken at $517 \mathrm{~nm}$, and the ability of the sample extract to scavenge $\mathrm{DPPH}^{*}$ was calculated. 


\section{Determination of reducing power}

The reducing power of samples was analyzed based on the procedure reported by Oyaizu (1986). In brief, $2.5 \mathrm{~mL}$ of sample extract, $2.5 \mathrm{~mL}$ of $200 \mathrm{mM}$ sodium phosphate buffer, $\mathrm{pH} 6.6$, and $2.5 \mathrm{~mL}$ of $1 \%$ potassium ferricyanide were mixed and subjected to incubation for 20 minutes at $50^{\circ} \mathrm{C}$. Afterwards, $2.5 \mathrm{~mL}$ of $10 \%$ trichloroacetic acid was dispensed into the reaction mixture, which was later divided into $2.5 \mathrm{~mL}$ aliquots in different test tubes. The content of each test tube was diluted with $2.5 \mathrm{~mL}$ of distilled $\mathrm{H}_{2} \mathrm{O}$, followed by addition of $1 \mathrm{~mL}$ of ferric chloride solution $(0.1 \%)$. Subsequently, the absorbance reading was taken at 700 $\mathrm{nm}$, and the reducing power of the samples was calculated based on gallic acid calibration curve.

\section{Data analysis}

One-way analysis of variance (ANOVA) was performed on the results of three independent determinations. Mean values were compared by least significant difference (LSD) test at $p<0.05$, using version 17 of SPSS statistical software. The $\mathrm{IC}_{50}$ (that is, the concentration of each sample that caused $50 \%$ inhibition of enzyme activity and the $\mathrm{SC}_{50}$ (that is, the concentration of each sample that scavenged $\mathrm{DPPH}^{*}$ by $50 \%$ ) were calculated using Graphpad Prism ${ }^{\circledR}$, version 4.0 (Sandiego, CA).

\section{Results and discussion}

\section{Bioactive constituents}

Table 1 presents the bioactive constituents of the yellow maize (YM) and cowpea $(\mathrm{CP})$ composite flours and biscuits. YM had the highest $(p<0.05)$ total carotenoids content, while CP had the highest $(p<0.05)$ total phenolics, tannins, total flavonoids and saponins contents. The total carotenoids content of the YM obtained in this study $(20.57 \pm 0.42 \mu \mathrm{g} / \mathrm{g})$ agrees closely with the concentration of total carotenoids (20.4 $\pm 0.2 \mu \mathrm{g} / \mathrm{g})$ reported by Taleon et al. (2017) in biofortified orange maize variety. In contrast, the total phenolics content of yellow maize $(300.25$ $\mathrm{mg} / 100 \mathrm{~g}$, equivalent to $3.00 \mathrm{mg} / \mathrm{g}$ ) reported by Oboh et al. (2010) is higher than the total phenolics content of the YM $(2.08 \pm 0.03 \mathrm{mg} / \mathrm{g})$ obtained in this study. Also, the total phenolics and flavonoids of the $\mathrm{CP}$ in this study $(9.20 \pm 0.06$ and $3.92 \pm 0.08 \mathrm{mg} / \mathrm{g}$, respectively) are lower than the total phenolics and flavonoids contents $(12.16 \pm 0.27$ and $7.24 \pm 0.20 \mathrm{mg} / \mathrm{g}$, respectively) reported by Sreerama et al. (2012).

The level of total carotenoids increased significantly $(p<0.05)$ with increasing proportion of YM, while the levels of total phenolics, tannins, total flavonoids and saponins increased with increasing proportion of $\mathrm{CP}$ in the composite flours and biscuits. Thus, YMCP-1 (composed of $75 \%$ YM and $25 \% \mathrm{CP}$ ) and its corresponding biscuit, YMCP-1B, had a significantly $(p<0.05)$ higher level of total carotenoids, while YMCP-3 (comprising 25\% YM and $75 \% \mathrm{CP}$ ) and its counterpart biscuit, YMCP-3B, had significantly $(p<0.05)$ higher levels of total phenolics, tannins, total flavonoids and saponins, than the other composite flours 
and biscuits. These trends suggest that YM was the major source of carotenoids, while CP was the major source of polyphenolics (total phenolics, tannins, total flavonoids) and saponins in the composite flours and biscuits. However, refined wheat flour (WT) and its corresponding biscuit (WT-B) had the lowest levels of all the bioactive components.

Table 1. Bioactive constituents of yellow maize and cowpea composite flours and biscuits

\begin{tabular}{|c|c|c|c|c|c|}
\hline Samples & $\begin{array}{l}\text { Total } \\
\text { carotenoids } \\
(\mu \mathrm{g} / \mathrm{g})\end{array}$ & $\begin{array}{l}\text { Total } \\
\text { phenolics } \\
\text { (mg GAE/g) }\end{array}$ & $\begin{array}{l}\text { Tannins } \\
\text { (mg TAE/g) }\end{array}$ & $\begin{array}{l}\text { Total } \\
\text { flavonoids } \\
\text { (mg QE/g) }\end{array}$ & $\begin{array}{l}\text { Total } \\
\text { saponins } \\
(\mathbf{m g ~ D E} / \mathrm{g}) \\
\end{array}$ \\
\hline \multicolumn{6}{|c|}{ Flour } \\
\hline YM & $20.57 \pm 0.42^{\mathrm{a}}$ & $2.08 \pm 0.03^{\mathrm{e}}$ & $1.98 \pm 0.01^{\mathrm{e}}$ & $0.93 \pm 0.03^{\mathrm{e}}$ & $0.92 \pm 0.02^{\mathrm{e}}$ \\
\hline YMCP-1 & $16.03 \pm 0.06^{\mathrm{b}}$ & $2.87 \pm 0.04^{\mathrm{d}}$ & $2.39 \pm 0.02^{\mathrm{d}}$ & $1.08 \pm 0.02^{\mathrm{d}}$ & $1.58 \pm 0.13^{\mathrm{d}}$ \\
\hline YMCP-2 & $9.92 \pm 0.21^{\mathrm{c}}$ & $3.26 \pm 0.06^{\mathrm{c}}$ & $2.93 \pm 0.04^{\mathrm{c}}$ & $1.89 \pm 0.04^{\mathrm{c}}$ & $2.71 \pm 0.06^{\mathrm{c}}$ \\
\hline YMCP-3 & $4.00 \pm 0.25^{\mathrm{d}}$ & $4.07 \pm 0.07^{b}$ & $3.26 \pm 0.01^{\mathrm{b}}$ & $2.65 \pm 0.03^{\mathrm{b}}$ & $3.74 \pm 0.11^{\mathrm{b}}$ \\
\hline $\mathrm{CP}$ & $0.94 \pm 0.04^{\mathrm{e}}$ & $9.20 \pm 0.06^{\mathrm{a}}$ & $5.71 \pm 0.04^{\mathrm{a}}$ & $3.92 \pm 0.08^{\mathrm{a}}$ & $6.19 \pm 0.12^{\mathrm{a}}$ \\
\hline WT & $0.21 \pm 0.01^{\mathrm{f}}$ & $0.63 \pm 0.04^{\mathrm{f}}$ & $0.53 \pm 0.01^{\mathrm{f}}$ & $0.15 \pm 0.01^{\mathrm{f}}$ & $0.28 \pm 0.01^{\mathrm{f}}$ \\
\hline \multicolumn{6}{|c|}{ Biscuits } \\
\hline YM-B & $13.94 \pm 0.19^{\mathrm{a}}$ & $1.61 \pm 0.03^{\mathrm{e}}$ & $1.48 \pm 0.11^{\mathrm{d}}$ & $0.67 \pm 0.03^{\mathrm{e}}$ & $0.71 \pm 0.01^{\mathrm{e}}$ \\
\hline YMCP-1B & $11.08 \pm 0.03^{\mathrm{b}}$ & $2.15 \pm 0.11^{\mathrm{d}}$ & $1.69 \pm 0.14^{\mathrm{d}}$ & $0.85 \pm 0.01^{\mathrm{d}}$ & $1.23 \pm 0.13^{\mathrm{d}}$ \\
\hline YMCP-2B & $6.41 \pm 0.20^{c}$ & $2.35 \pm 0.12^{\mathrm{c}}$ & $2.09 \pm 0.01^{\mathrm{c}}$ & $1.19 \pm 0.12^{\mathrm{c}}$ & $2.11 \pm 0.11^{\mathrm{c}}$ \\
\hline YMCP-3B & $2.80 \pm 0.17^{\mathrm{d}}$ & $3.08 \pm 0.08^{b}$ & $2.56 \pm 0.01^{\mathrm{b}}$ & $2.00 \pm 0.03^{\mathrm{b}}$ & $3.01 \pm 0.01^{b}$ \\
\hline CP-B & $0.52 \pm 0.02^{\mathrm{e}}$ & $7.00 \pm 0.06^{\mathrm{a}}$ & $4.38 \pm 0.11^{\mathrm{a}}$ & $3.00 \pm 0.02^{\mathrm{a}}$ & $5.04 \pm 0.11^{\mathrm{a}}$ \\
\hline WT-B & $0.32 \pm 0.01^{\mathrm{e}}$ & $0.50 \pm 0.02^{\mathrm{f}}$ & $0.42 \pm 0.01^{\mathrm{e}}$ & $0.10 \pm 0.00^{\mathrm{f}}$ & $0.21 \pm 0.01^{\mathrm{f}}$ \\
\hline
\end{tabular}

Results are mean \pm standard deviation (SD) of independent triplicate determinations. Along the same column, values having different superscript letters vary significantly $(p<0.05)$. YM, $100 \%$ yellow maize flour; YMCP-1, 75:25 (\% w/w) yellow maize and cowpea composite flour; YMCP-2, 50:50 (\% w/w) yellow maize and cowpea composite flour; YMCP-3, 25:75 (\% w/w) yellow maize and cowpea composite flour; CP, 100\% cowpea flour; WT, 100\% refined wheat flour; YM-B, yellow maize biscuit; YMCP-1B, 75:25 (\% w/w) yellow maize and cowpea composite biscuit; YMCP-2B, 50:50 $(\% \mathrm{w} / \mathrm{w})$ yellow maize and cowpea composite biscuit; YMCP-3B, 25:75 (\% w/w) yellow maize and cowpea composite biscuit; CP-B, cowpea biscuit; WT-B, refined wheat flour biscuit

Carotenoids are well-known for their health benefits including vitamin A activity (Elemosho et al., 2020), protection against chronic diseases, for example, cardiovascular diseases (Gammone et al., 2017) and antioxidant activity, which has been identified as the main mechanism underpinning their health benefits (Seifried et al., 2007). In addition, Sugiura et al. (2015) reported that consumption of carotenoids-rich diets may confer protection against the development of T2D. On the other hand, polyphenolics such as tannins and flavonoids are notable for their health benefits, including antidiabetic and antioxidant (Bai et al., 2017), antihypertensive and anti-obesity Irondi et al., 2018b) activities. Similarly, saponins 
were reported to possess anti-diabetic (Lu et al., 2016), antioxidant (Guo et al., 2018) and anti-obesity (Chen et al., 2017) activities.

The levels of all the bioactive constituents, except total carotenoids, decreased in the composite biscuits relative to their corresponding flours (Table 1). This decrease may be attributed to the thermal degradation and oxidation of the bioactive constituents induced by heat (Irondi et al., 2019a; Rawson et al., 2013) during baking. For the phenolic compounds, their oxidation induced by heat is known to promote the formation of Maillard reaction products in food products (Lin et al., 2016).

\section{Enzymes inhibitory activity}

The results of enzymes (pancreatic lipase, $\alpha$-amylase and $\alpha$-glucosidase) inhibitory activity of the yellow maize and cowpea composite flours and biscuits are presented in Table 2 in terms of their $\mathrm{IC}_{50}$ values. Among the flours, CP had the lowest $\mathrm{IC}_{50}$ values, indicating the strongest inhibitory activity towards the tested enzymes, while WT had the highest $\mathrm{IC}_{50}$ value (the weakest inhibitory effect). Relative to the $\mathrm{IC}_{50}$ values reported for red sorghum variety against $\alpha$-amylase, $\alpha$ glucosidase and pancreatic lipase $(16.93 \pm 1.08,10.78 \pm 0.63$ and $12.72 \pm 1.13$ $\mu \mathrm{g} / \mathrm{mL}$, respectively) (Irondi et al., 2019a), the $\mathrm{IC}_{50}$ values of the YM used in this study against the same enzymes $(237.12 \pm 2.60,157.18 \pm 1.05$ and $138.02 \pm 1.77$ $\mu \mathrm{g} / \mathrm{mL}$, respectively) are higher. Similarly, the $\mathrm{IC}_{50}$ values of the $\mathrm{CP}$ variety (IT10K-837-1) used in this study against $\alpha$-amylase, $\alpha$-glucosidase and pancreatic lipase $(147.34 \pm 0.80,97.17 \pm 1.20$ and $62.93 \pm 0.49 \mu \mathrm{g} / \mathrm{mL}$, respectively) are generally higher than the values earlier reported for Ife Brown, another variety of cowpea, against the same enzymes $(132.91 \pm 5.37,76.74 \pm 3.02$ and $53.08 \pm 4.13$ $\mu \mathrm{g} / \mathrm{mL}$, respectively) (Irondi et al., 2019b). The variations in the $\mathrm{IC}_{50}$ values obtained in this study against the tested enzymes and those previously reported, in the case of cowpea, may be attributed to differences in the sample extraction methods, genotype and environmental factors (Mpofu et al., 2006).

Consistently, among the composite flours and their counterpart biscuits, the $\mathrm{IC}_{50}$ values decreased with increasing proportion of $\mathrm{CP}$, such that YMCP-3 and YMCP$3 \mathrm{~B}$ had the least $\mathrm{IC}_{50}$ values (the strongest inhibitory activity) towards the tested enzymes. Furthermore, the $\mathrm{IC}_{50}$ values of the biscuits towards the tested enzymes increased relative to their corresponding flours, indicating a decreasing inhibitory activity. This may be attributed to the observed decrease in the levels of bioactive constituents in the biscuits, in comparison to their corresponding flours (Table 1). The bioactive constituents analyzed in the flours and biscuits, including total phenolics, tannins, total flavonoids (phenolic compounds) and saponins, have been shown to inhibit digestive enzymes, including pancreatic lipase, $\alpha$-amylase and $\alpha$ glucosidase (Irondi et al., 2019a; Liu and Xu, 2015). Phenolic compounds, for instance, have a high affinity for proteins through hydrogen and hydrophobic interactions; a property that enables them to inhibit digestives enzymes by protein denaturation (Villiger et al., 2015). Consequently, the thermal degradation and heat-induced oxidation of the bioactive constituents was accompanied by a decrease in their enzymes inhibitory activity. 
Table 2. $\mathrm{IC}_{50}$ values of yellow maize and cowpea composite flours and biscuits extracts on $\alpha$-amylase, $\alpha$-glucosidase and pancreatic lipase activity.

\begin{tabular}{|c|c|c|c|c|}
\hline Samples & $\begin{array}{l}\alpha \text {-amylase } \\
(\mu \mathrm{g} / \mathrm{mL})\end{array}$ & $\begin{array}{l}\alpha \text {-glucosidase } \\
(\mu \mathrm{g} / \mathrm{mL})\end{array}$ & $\begin{array}{l}\text { Pancreatic } \\
(\mu \mathrm{g} / \mathrm{mL})\end{array}$ & lipase \\
\hline \multicolumn{5}{|c|}{ Flours } \\
\hline YM & $237.12 \pm 2.60^{\mathrm{b}}$ & $157.18 \pm 1.05^{\mathrm{b}}$ & $138.02 \pm 1.77^{b}$ & \\
\hline YMCP-1 & $208.36 \pm 1.61^{\mathrm{c}}$ & $135.98 \pm 1.82^{\mathrm{c}}$ & $106.75 \pm 1.41^{\mathrm{c}}$ & \\
\hline YMCP-2 & $171.45 \pm 1.09^{\mathrm{d}}$ & $112.20 \pm 1.06^{\mathrm{d}}$ & $80.72 \pm 0.40^{\mathrm{d}}$ & \\
\hline YMCP-3 & $160.14 \pm 0.71^{\mathrm{de}}$ & $105.17 \pm 0.62^{\mathrm{de}}$ & $71.39 \pm 0.94^{\mathrm{e}}$ & \\
\hline $\mathrm{CP}$ & $147.34 \pm 0.80^{\mathrm{e}}$ & $97.17 \pm 1.20^{\mathrm{e}}$ & $62.93 \pm 0.49^{f}$ & \\
\hline WT & $1353.47 \pm 16.94^{\mathrm{a}}$ & $891.66 \pm 11.16^{\mathrm{a}}$ & $343.50 \pm 3.66^{\mathrm{a}}$ & \\
\hline \multicolumn{5}{|c|}{ Biscuits } \\
\hline YM-B & $274.69 \pm 2.99^{b}$ & $181.69 \pm 2.35^{\mathrm{b}}$ & $166.85 \pm 2.72^{b}$ & \\
\hline YMCP-1B & $241.62 \pm 1.98^{c}$ & $152.52 \pm 2.88^{\mathrm{c}}$ & $124.19 \pm 1.93^{c}$ & \\
\hline YMCP-2B & $199.17 \pm 1.58^{\mathrm{d}}$ & $137.41 \pm 1.92^{\mathrm{d}}$ & $96.02 \pm 1.87^{\mathrm{d}}$ & \\
\hline YMCP-3B & $186.66 \pm 2.94^{\mathrm{e}}$ & $121.39 \pm 1.41^{\mathrm{e}}$ & $83.38 \pm 1.75^{\mathrm{e}}$ & \\
\hline CP-B & $171.44 \pm 1.90^{\mathrm{f}}$ & $111.27 \pm 2.07^{\mathrm{f}}$ & $72.74 \pm 2.27^{\mathrm{f}}$ & \\
\hline WT-B & $1505.49 \pm 3.92^{\mathrm{a}}$ & $1020.50 \pm 4.24^{\mathrm{a}}$ & $392.09 \pm 3.46^{\mathrm{a}}$ & \\
\hline Acarbose $(\mu \mathrm{g} / \mathrm{mL})$ & $11.46 \pm 0.95^{\mathrm{f}}$ & $19.37 \pm 1.04^{\mathrm{f}}$ & - & \\
\hline Orlistat $(\mu \mathrm{g} / \mathrm{mL})$ & - & - & $1.14 \pm 0.04^{\mathrm{g}}$ & \\
\hline
\end{tabular}

Results areaverage values \pm standard deviations of triplicate analyses. Values with different superscript alphabets along the same column, differ significantly at $p<0.05$. YM, $100 \%$ yellow maize flour; YMCP-1, 75:25 (\% w/w) yellow maize and cowpea composite flour; YMCP-2, 50:50 (\% $\mathrm{w} / \mathrm{w})$ yellow maize and cowpea composite flour; YMCP-3, 25:75 (\% w/w) yellow maize and cowpea composite flour; CP, 100\% cowpea flour; WT, 100\% refined wheat flour; YM-B, yellow maize biscuit; YMCP-1B, 75:25 (\% w/w) yellow maize and cowpea composite biscuit; YMCP-2B, 50:50 $(\% \mathrm{w} / \mathrm{w})$ yellow maize and cowpea composite biscuit; YMCP-3B, 25:75 (\% w/w) yellow maize and cowpea composite biscuit; CP-B, cowpea biscuit; WT-B, refined wheat flour biscuit; IC50: concentration of extract that inhibited enzyme activity by $50 \%$.

The pattern of inhibition of the tested enzymes indicates that both the flours and biscuits had the strongest inhibitory effect on pancreatic lipase, followed by $\alpha$ glucosidase and then $\alpha$-amylase. This pattern may have an important implication in the management of obesity and T2D. First, by inhibiting pancreatic lipase, the flours and biscuits may retard the rate of production and the subsequent accumulation of fatty acids, which represents an important clinical approach for treating obesity (Irondi et al., 2018b). Moreover, since obesity is a major predisposing factor to T2D (Gomez-Ambrosi et al., 2011), a stronger inhibition of pancreatic lipase is desirable to forestall obesity-induced diabetogenesis.

Relative to acarbose, an oral hypoglycaemic drug that inhibits $\alpha$-amylase and $\alpha$ glucosidase, the flours and biscuits inhibited $\alpha$-glucosidase more than $\alpha$-amylase. This inhibition pattern is in agreement with the trend of inhibition of these two enzymes reported by previous studies (Irondi et al., 2014; Figueiredo-Gonzalez et 
al., 2015). This ability of the flours and biscuits to inhibit $\alpha$-glucosidase more than $\alpha$-amylase suggests that the side effects that characterize the clinical use of acarbose, such as flatulence and abdominal distention, which stem from acarbose's stronger inhibitory effect on $\alpha$-amylase than on $\alpha$-glucosidase (Dalar and Konczak, 2013, may not occur in the case of the flours and biscuits.

Table 3. Antioxidant activity of yellow maize and cowpea composite flours and biscuits extracts.

\begin{tabular}{|c|c|c|c|}
\hline Samples & $\begin{array}{c}\text { ABTS }^{*+} \text { scavenging } \\
\text { ability }(\mu \mathrm{mol} \text { TEAC/g })\end{array}$ & $\begin{array}{l}\text { DPPH* } \\
(\mu \mathrm{g} / \mathrm{mL})\end{array}$ & $\begin{array}{l}\text { Reducing power } \\
\text { (mg GAE/g) }\end{array}$ \\
\hline \multicolumn{4}{|c|}{ Flours } \\
\hline YM & $294.81 \pm 2.23^{\mathrm{e}}$ & $52.83 \pm 0.74^{b}$ & $7.92 \pm 0.26^{\mathrm{e}}$ \\
\hline YMCP-1 & $316.56 \pm 1.11^{\mathrm{d}}$ & $47.59 \pm 0.48^{c}$ & $13.15 \pm 0.38^{\mathrm{d}}$ \\
\hline YMCP-2 & $339.61 \pm 2.17^{\mathrm{c}}$ & $45.31 \pm 0.57^{\mathrm{c}}$ & $21.22 \pm 0.25^{\mathrm{c}}$ \\
\hline YMCP-3 & $353.77 \pm 3.34^{\mathrm{b}}$ & $40.49 \pm 0.54^{\mathrm{d}}$ & $29.02 \pm 0.23^{b}$ \\
\hline $\mathrm{CP}$ & $367.49 \pm 3.32^{\mathrm{a}}$ & $33.89 \pm 0.35^{\mathrm{e}}$ & $39.31 \pm 0.57^{\mathrm{a}}$ \\
\hline WT & $174.58 \pm 1.10^{\mathrm{f}}$ & $645.27 \pm 2.69^{\mathrm{a}}$ & $2.16 \pm 0.01^{\mathrm{f}}$ \\
\hline \multicolumn{4}{|c|}{ Biscuits } \\
\hline YM-B & $327.68 \pm 3.20^{\mathrm{e}}$ & $43.17 \pm 0.39^{b}$ & $8.43 \pm 0.14^{\mathrm{e}}$ \\
\hline YMCP-1B & $357.54 \pm 1.58^{\mathrm{d}}$ & $38.55 \pm 0.34^{\mathrm{c}}$ & $14.38 \pm 0.30^{\mathrm{d}}$ \\
\hline YMCP-2B & $378.36 \pm 1.02^{\mathrm{c}}$ & $36.16 \pm 0.47^{d}$ & $23.96 \pm 0.21^{\mathrm{c}}$ \\
\hline YMCP-3B & $393.72 \pm 2.63^{b}$ & $32.01 \pm 0.17^{\mathrm{e}}$ & $33.07 \pm 0.13^{b}$ \\
\hline CP-B & $411.09 \pm 1.61^{\mathrm{a}}$ & $27.99 \pm 0.30^{\mathrm{f}}$ & $46.22 \pm 0.35^{\mathrm{a}}$ \\
\hline WT-B & $193.24 \pm 1.20^{\mathrm{f}}$ & $528.12 \pm 0.62^{\mathrm{a}}$ & $2.78 \pm 0.20^{\mathrm{f}}$ \\
\hline Ascorbic acid & - & $7.52 \pm 0.81^{\mathrm{f}}$ & - \\
\hline
\end{tabular}

Results are means \pm standard deviations (SD) of triplicate determinations. Along the same column, values having different superscript letters vary significantly $(p<0.05)$. YM, 100\% yellow maize flour; YMCP-1, 75:25 (\% w/w) yellow maize and cowpea composite flour; YMCP-2, 50:50 (w/w) yellow maize and cowpea composite flour; YMCP-3, 25:75 (\% w/w) yellow maize and cowpea composite flour; CP, 100\% cowpea flour; WT, 100\% refined wheat flour; YM-B, yellow maize biscuit; YMCP-1B, 75:25 (\% w/w) yellow maize and cowpea composite biscuit; YMCP-2B, 50:50 $(\% \mathrm{w} / \mathrm{w})$ yellow maize and cowpea composite biscuit; YMCP-3B, 25:75 (\% w/w) yellow maize and cowpea composite biscuit; CP-B, cowpea biscuit; WT-B, refined wheat flour biscuit; $\mathrm{SC}_{50}$ : extract concentration that scavenged $50 \%$ of $\mathrm{DPPH}^{*}$

\section{Antioxidant activity}

Table 3 presents the antioxidant activity of the yellow maize and cowpea composite flours and biscuits, as tested using free radicals $\left(\mathrm{ABTS}^{*+}\right.$ and $\left.\mathrm{DPPH}^{*}\right)$ scavenging assays and reducing power. As with the enzymes inhibitory results (Table 2), CP had the strongest $(p<0.05) \mathrm{ABTS}^{*+}$ and $\mathrm{DPPH}^{*}$ scavenging ability and the highest $(p<0.05)$ reducing power, while WT had the weakest $\mathrm{ABTS}^{*+}$ and $\mathrm{DPPH}^{*}$ scavenging ability and the least reducing power. Compared to the DPPH $\mathrm{SC}_{50}$ range $(15.4-40.2 \mathrm{mg} / \mathrm{mL})$ in orange maize hybrids recently reported by 
Alamu et al. (2021), the YM used in this study had a lower $\mathrm{DPPH}^{*} \mathrm{SC}_{50}$ of 52.83 $\mu \mathrm{g} / \mathrm{mL}(0.05 \mathrm{mg} / \mathrm{mL})$, indicating a stronger DPPH* scavenging activity. Similarly, the $\mathrm{DPPH}^{*} \mathrm{SC}_{50}$ of the CP in this study $(33.89 \mu \mathrm{g} / \mathrm{mL})$ is lower than the $\mathrm{DPPH}^{*}$ $\mathrm{IC}_{50}(48.2 \pm 1.9 \mu \mathrm{g} / \mathrm{mL})$ earlier reported for cowpea flour by Sreerama et al. (2012). It well-known that a lower $\mathrm{DPPH}^{*} \mathrm{SC}_{50}$ value represents a stronger capacity of a sample to scavenge DPPH* (Irondi et al., 2019c).

The $\mathrm{ABTS}^{*+}$ and $\mathrm{DPPH}^{*}$ scavenging ability, and reducing power of the composite flours and their corresponding biscuits increased as the proportion of $\mathrm{CP}$ in the flours and biscuits increased, such that YMCP-3 and its counterpart biscuit, YMCP-3B, had the strongest $\mathrm{ABTS}^{*+}$ and $\mathrm{DPPH}^{*}$ scavenging ability and the highest reducing power among the composite flours and biscuits, respectively.

The $\mathrm{ABTS}^{*+}$ and $\mathrm{DPPH}^{*}$ scavenging ability, and reducing power of the biscuits were consistently higher than those of their corresponding flours. This is contrary to the trend observed in the enzymes inhibitory activity, in which the biscuits had weaker inhibitory effects on the tested enzymes (Table 2). The higher antioxidant activity of the biscuits relative to their corresponding flours may be attributed to the Maillard reaction products that may have been formed during baking. Maillard reaction products such as melanoidins and reductones, formed at the expense of polyphenolic compounds in food matrices during thermal treatment, exhibit antioxidant activity (Irondi et al., 2019b; Samaras et al., 2005). Thus, the biscuits, when eaten, may have enhanced capacity to mitigate the formation of free radicals and reactive oxygen species, thereby preventing and/or extenuating oxidative stress, obesity and T2D. This is supported by an earlier report by Irondi et al. (2018) that boosting the antioxidant capacity of the cell is vital for the treatment of various metabolic diseases.

\section{Conclusions}

The level of total carotenoids increased as the proportion of biofortified yellow maize increased, while the levels of total phenolics, tannins, total flavonoids and saponins, enzymes inhibitory and antioxidant activities increased as the proportion of cowpea increased in the composite flours and biscuits. Among the composite flours and biscuits, YMCP-3 (comprising 25\% yellow maize and 75\% cowpea) and its corresponding biscuit, YMCP-3B, had the strongest enzymes inhibitory and antioxidant activities. Hence, the composite biscuits, especially YMCP-3B, may be beneficial in retarding the rate of production of fatty acids and glucose formation, and mitigating oxidative stress, which are important clinical strategies for managing obesity and T2D.

\section{Acknowledgments}

The authors gratefully acknowledge the Tertiary Education Trust Fund (TETFund) of Nigeria for providing funding under the institution-based research grant (KWASUIBR/CSP/250918/VOL5/TETF/0054) to support this research project. 


\section{Conflict of interest statement}

The authors do not have any conflict of interest to declare.

\section{References}

Aggarwal, D., Sabikhi, L., Kumar, M.H.S. 2016. Formulation of reduced-calorie biscuits using artificial sweeteners and fat replacer with dairy-multigrain approach. NFS Journal, 2, 1-7.

Alamu, E.O., Maziya-Dixon, B., Menkir, A., Olaofe, O. 2018. Bioactive compounds of freshly harvested open pollinated varieties (OPV) of orange maize (Zea mays): Varietal, maturity, and boiling methods effects. Cogent Chemistry, 4, 1507489.

Alamu E.O., Maziya-Dixon B., Menkir A., Irondi E.A., Olaofe O., 2021. Bioactive composition and free radical scavenging activity of fresh orange maize hybrids: impacts of genotype, maturity stages and processing methods. Frontiers in Nutrition, 8: 640563.

Alzaman, N., Ali, A., 2016. Obesity and diabetes mellitus in the Arab world. Journal of Taibah University of Medical Sciences, 11, 301-309.

American Diabetes Association, ADA, 2012. Standards of medical care in diabetes - 2012. Diabetes Care, 35, S11-S63.

Amorim, E.L.C., Nascimento, J.E., Monteiro, J.M., Sobrinho, P., Araujo, T.A.S., Albuquerque, U.A.P., 2008. A simple and accurate procedure for the determination of tannins and flavonoid levels and some applications in ethnobotany and ethnopharmacology. Functional Ecosystems and Communities, 2, 88-94.

Awika, J.M., Duodu, K.G., 2017. Bioactive polyphenols and peptides in cowpea (Vigna unguiculata) and their health promoting properties: A review. Journal of Functional Foods, 38, 686-697.

Bae, J.P., Lage, M.J., Nelson, D.R., Hoogwerf, B.J., 2016. Obesity and glycemic control in patients with diabetes mellitus: Analysis of physician electronic health records in the US from 20092011. Journal of Diabetes Complications, 30, 212-220.

Bai, Y., Xu, Y., Wang, B., Li, S., Guo, F., Hua, H., Zhao, Y., Yu, Z., 2017. Comparison of phenolic compounds, antioxidant and antidiabetic activities between selected edible beans and their different growth periods leaves. Journal of Functional Foods, 35, 694-702.

Beta, T., Hwang, T., 2018. Influence of heat and moisture treatment on carotenoids, phenolic content, and antioxidant capacity of orange maize flour. Food Chemistry, 246, 58-64.

Cervato, G., Carabelli, M., Gervasio, S., Cittera, A., Cazzola, R., Cestaro, B., 2000. Antioxidant properties of oregano (Origanum vulgare) leaf extracts. Journal of Food Biochemistry, 24, 453-465.

Chen, G., Li, H., Zhao, Y., Zhu, H., Cai, E., Gao, Y., Liu, S., Yang, H., Zhang, L., 2017. Saponins from stems and leaves of Panax ginseng prevent obesity via regulating thermogenesis, lipogenesis and lipolysis in high-fat diet-induced obese C57BL/6 mice. Food and Chemical Toxicology, 106, 393-403.

Cukelj, N., Novotni, D., Sarajlija, H., Drakula, S., Voucko, B., Curic, D., 2017. Flaxseed and multigrain mixtures in the development of functional biscuits. LWT - Food Science and Technology, 86, 85-92.

Dalar, A., Konczak, I., 2013. Phenolic contents, antioxidant capacities and inhibitory activities against key metabolic syndrome relevant enzymes of herbal teas from Eastern Anatolia. Industrial Crops and Products, 4, 383-390. 
Elemosho, A.O., Irondi, E.A., Alamu, E.O., Ajani, E.O., Maziya-Dixon, B., Menkir, A., 2020. Characterization of Striga-resistant yellow-orange maize hybrids for bioactive, carbohydrate, and pasting properties. Frontiers in Sustainable Food Systems, 4, 585865.

Engida, A.M., Kasim, N.S., Tsigie, Y.A., Ismadji, S., Huynh, L.H., Ju, Y., 2013. Extraction, identification and quantitative HPLC analysis of flavonoids from sarang semut (Myrmecodia pendan). Industrial Crops and Products, 41, 392-396.

Eom, S.H., Lee, M.S., Lee, E.W., Kim, Y.M., Kim, T.H., 2013. Pancreatic lipase inhibitory activity of phlorotannins isolated from Eisenia bicyclis. Phytotherapy Research, 27, 148-151.

Fardet, A., 2010. New hypotheses for the health-protective mechanisms of whole grain cereals: what is beyond fibre? Nutrition Research Reviews, 23, 65-134.

Figueiredo-Gonzalez, M., Grosso, C., Valentao, P., Andrade, P.B., 2015. $\alpha$-Glucosidase and $\alpha$ amylase inhibitors from Myrcia spp.: a stronger alternative to acarbose? Journal of Pharmaceutical and Biomedical Analysis, 118, 322-327.

Gammone, M.A., Pluchinotta, F.R., Bergante, S., Tettamanti, G., D’Orazio, N., 2017. Prevention of cardiovascular diseases with carotenoids. Frontiers in Bioscience, 9, 165-171.

Gomez-Ambrosi, J., Silva, C., Galofre, J.C., Escalada, J., Santos, S., Gil, M.J., Valentí, V., Rotellar, F., Ramírez B., Salvador, J., Frühbeck, G., 2011. Body adiposity and type 2 diabetes: increased risk with a high body fat percentage even having a normal BMI. Obesity (Silver Spring), 19, 1439-1444.

Guo, N., Tong, T., Ren, N., Tu, Y., Li, B., 2018. Saponins from seeds of Genus Camellia: Phytochemistry and bioactivity. Phytochemistry, 149, 42-55.

Hossain, P., Kawar, B., El Nahas, M., 2007. Obesity and diabetes in the developing world - a growing challenge. New England Journal of Medicine, 356, 213-215.

Irondi, E.A., Adegoke, B.M., Effion, E.S., Oyewo, S.O., Alamu, E.O., Boligon, A.A., 2019a. Enzymes inhibitory property, antioxidant activity and phenolics profile of raw and roasted red sorghum grains in vitro. Food Science and Human Wellness, 8, 142-148.

Irondi, E.A., Agboola, S.O., Boligon, A.A., 2018b. Inhibitory effects of tropical almond leaf extract on xanthine oxidase, pancreatic lipase, and angiotensin I-converting enzyme, in vitro. Journal of Food Biochemistry, 42, e12481.

Irondi, E.A., Awoyale, W., Oboh, G., Boligon, A.A., 2019c. Phenolics composition, antioxidant and pasting properties of high-quality cassava flour substituted with Brachystegia eurycoma seed flour. The Annals of the University Dunarea de Jos of Galati, Fascicle VI - Food Technology, 43(1), 9-23.

Irondi, E.A., Mohammed, R.O., Balogun, A.F., Tajudeen, H.I., Aleshinloye, O.M., 2018a. Antioxidant and modulatory properties of kernel flour extracts of three Nigerian local mango varieties on enzymes relevant to metabolic syndrome. Oxidants and Antioxidants in Medical Science, 8, 1-10.

Irondi, E.A., Oboh, G., Akindahunsi, A.A., Boligon, A.A., Athayde, M.L., 2014. Phenolic composition and inhibitory activity of Mangifera indica and Mucuna urens seeds extracts against key enzymes linked to the pathology and complications of type 2 diabetes. Asian Pacific Journal of Tropical Biomedicine, 4, 903-910.

Irondi, E.A., Ogunsanmi, A.O., Ahmad, R.S., Ajani, E.O., Adegoke, B.M., Boligon, A.A., 2019b. Effect of roasting on phenolics composition, enzymes inhibitory and antioxidant properties of cowpea pulses. Journal of Food Measurement and Characterization, 13, 1489-1496. 
Kim, Y.M., Jeong, Y.K., Wang, M.H., Lee, Y.H., Rhee, H.I., 2005. Inhibitory effect of pine extract on alpha-glucosidase activity and postprandial hyperglycaemia. Nutrition, 21, 756-761.

Kwon, Y.I., Apostolidis, E., Shetty, K., 2008. Inhibitory potential of wine and tea against $\alpha-$ amylase and a-glucosidase for management of hyperglycemia linked to type 2 diabetes. Journal of Food Biochemistry, 32, 15-31.

Li, Y.Q., Yang, P., Gao, F., Zhang, Z.W., Wu, B., 2011. Probing the interaction between 3 flavonoids and pancreatic lipase by methods of fluorescence spectroscopy and enzymatic kinetics. European Food Research and Technology, 233, 63-69.

Lin, J.-T., Liu, S.-C., Hu, C.-C., Shyu, Y.-S., Hsu, C.-Y., Yang, D.-J., 2016. Effects of roasting temperature and duration on fatty acid composition, phenolic composition, Maillard reaction degree and antioxidant attribute of almond (Prunus dulcis) kernel. Food Chemistry, 190, 520 528.

Liu, R., Xu, B., 2015. Inhibitory Effects of Phenolics and Saponins from commonly consumed food legumes in china against digestive enzymes pancreatic lipase and $\alpha$-glycosidase. International Journal of Food Property, 18, 2246-2255.

Lu, J., Wang, Y., Yan, H., Lin, P., Gu, W., Yu, J., 2016. Antidiabetic effect of total saponins from Polygonatum kingianum in streptozotocin-induced daibetic rats. Journal of Ethnopharmacology, 179, 291-300.

Makkar, H.P.S., Siddhuraju, P., Becker, K., 2007. Plant Secondary Metabolites. Humana Press Inc., Totowa, NJ, USA.

Martinez-Saez, N., Hochkogler, C.M., Somoza, V., del Castillo, M.D., 2017. Biscuits with no added sugar containing stevia, coffee fibre and fructooligosaccharides modifies $\alpha$-glucosidase activity and the release of GLP-1from HuTu-80 cells and serotonin from Caco- 2 cells after in vitro digestion. Nutrition, 9, 694.

Meda, A., Lamien, C.E., Romito, M., Millogo, J., Nacoulma, O.G., 2005. Determination of the total phenolic, flavonoid and proline contents in Burkina Fasan honey, as well as their radical scavenging activity. Food Chemistry, 91, 571-577.

Mpofu, A., Sapirstein, H.D., Beta. T., 2006. Genotype and environmental variation in phenolic content, phenolic acid composition, and antioxidant activity of hard spring wheat. Journal of Agricultural and Food Chemistry, 54, 1265-1270.

Oboh, G., Ademiluyi, A.O., Akindahunsi, A.A., 2010. The effect of roasting on the nutritional and antioxidant properties of yellow and white maize varieties. International Journal of Food Science and Technology, 45, 1236-1242.

Oyaizu, M., 1986. Studies on products of browning reaction: antioxidative activity of products of browning reaction prepared from glucosamine. Japan Journal of Nutrition, 44, 307-315.

Rani, V., Deep, G., Singh, R.K., Palle, K., Yadav, U.C.S., 2016. Oxidative stress and metabolic disorders: Pathogenesis and therapeutic strategies. Life Science, 148, 183-193.

Rawson, A., Hossain, M.B., Patras, A., Tuohy, M., Brunton, N., 2013. Effect of boiling and roasting on the polyacetylene and polyphenol content of fennel (Foeniculum vulgare) bulb. Food Research International, 50, 513-518.

Re, R., Pellegrini, N., Proteggente, A., Pannala, A., Yang, M., Rice-Evans, C., 1999. Antioxidant activity applying an improved ABTS radical cation decolorization assay. Free Radical Biology and Medicine, 26, 1231-1237.

Rodriguez-Amaya, D.B., 1999. A guide to carotenoid analysis in foods. ILSI Press, Washington DC. 
Saha, S., Gupta, A., Singh, S.R.K., Bharti, N., Singh, K.P., Mahajan, V., Gupta, H.S., 2011. Compositional and varietal influence of finger millet flour on rheological properties of dough and quality of biscuit. LWT - Food Science and Technology, 44, 616-621.

Samaras, T.S., Camburn, P.A., Chandra, S.X., Gordon, M.H., Ames, J.M., 2005. Antioxidant properties of kilned and roasted malts. Journal of Agricultural and Food Chemistry, 53, 80688074.

Segura-Campos, M.R., Chel-Guerrero, L.A., Betancur-Ancona, D.A., 2011. Purification of angiotensin I-converting enzyme inhibitory peptides from a cowpea (Vigna unguiculata) enzymatic hydrolysate. Process Biochemistry, 46, 864-872.

Seifried, H.E., Anderson, D.E., Fisher, E.I., Milner, J.A., 2007. A review of the interaction among dietary antioxidants and reactive oxygen species. Journal Nutritional Biochemistry, 18, 567579.

Singleton, V.L., Orthofer, R., Lamuela-Raventos, R.M., 1999. Analysis of total phenols and other oxidation substrates and antioxidants by means of Folin-Ciocalteau's reagent. Methods in Enzymology, 299, 152-178.

Sreerama, Y.N., Takahashi, Y., Yamaki, K., 2012. Phenolic antioxidants in some Vigna species of legumes and their distinct inhibitory effects on $\alpha$-glucosidase and pancreatic lipase activities. Journal of Food Science, 77, C927-933.

Sugiura, M., Nakamura, M., Ogawa, K., Ikoma, Y., Yano, M., 2015. High-serum carotenoids associated with lower risk for developing type 2 diabetes among Japanese subjects: Mikkabi cohort study. BMJ Open Diabetes Research \& Care, 3, e000147.

Sugiyama, H., Akazome, Y., Shoji, T., Yamaguchi, A., Yasue, M., Kanda, T., 2007. Oligomeric procyanidins in apple polyphenol are main active components for inhibition of pancreatic lipase and triglyceride absorption. Journal of Agricultural and Food Chemistry, 55, 4604-4609.

Taleon, V., Mugode, L., Cabrera-Soto, L., Palacios-Rojas, N., 2017. Carotenoid retention in biofortified maize using different post-harvest storage and packaging methods. Food Chemistry, 232, 60-66.

The GBD (Global Burden of Disease) 2015 Obesity Collaborators, 2017. Health effects of overweight and obesity in 195 countries over 25 years. New England Journal of Medicine, 377, 13-27.

Tucci, S.A., Boyland, E.J., Halford, J.C.G., 2010. The role of lipid and carbohydrate digestive enzyme inhibitors in the management of obesity: a review of current and emerging therapeutic agents. Diabetes, Metabolic Syndrome and Obesity, 3, 125-143.

Van Kleef, E., Van Trijp, J.C.M., Van Den Borne, J.J.G.C., Zondervan, C., 2012. Successful development of satiety enhancing food products: Towards a multidisciplinary agenda of research challenges. Critical Reviews in Food Science and Nutrition, 52, 611-628.

Villiger, A., Sala, F., Suter, A., Butterweck, V., 2015. In vitro inhibitory potential of Cynara scolymus, Silybum marianum, Taraxacum officinale, and Peumus boldus on key enzymes relevant to metabolic syndrome. Phytomedicine, 22, 138-144.

Wander, P.L., Boyko, E.J., Leonetti, D.L., McNeely, M.J., Kahn, S.E., Fujimoto, W.Y., 2012. Change in visceral adiposity independently predicts a greater risk of developing type 2 diabetes over 10 years in Japanese Americans. Diabetes Care, 36, 289-293.

Žilić, S., Serpen, A., Akıllığlu, G., Gökmen, V., Vančetović, J., 2012. Phenolic compounds, carotenoids, anthocyanins, and antioxidant capacity of colored maize (Zea mays L.) kernels. Journal of Agricultural and Food Chemistry, 60, 1224-1231. 